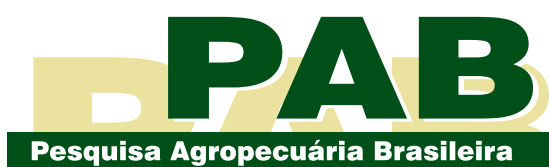

ISSN 1678-3921

Journal homepage: www.embrapa.br/pab

For manuscript submission and journal contents, access: www.scielo.br/pab

\section{Uni- and multivariate methods applied to the study of the adaptability and stability of white oat}

\begin{abstract}
The objective of this work was to compare uni- and multivariate biometric methods to evaluate the adaptability and stability of an important group of white oat (Avena sativa) cultivars grown in Southern Brazil. The used experimental design was a randomized complete block, in a factorial arrangement of 12 environments $\times 7$ cultivars, with three replicates. The analysis of variance and the methods of Eberhart \& Russel, Annicchiarico, and the harmonic mean of the relative performance of predicted genetic values (MHPRVG) were assessed. In the general comparison of the methods, the 'UPFA Gaudéria' and 'URS Guapa' genotypes were more stable regarding grain yield. The 'UPFA Gaudéria' and 'URS-21' genotypes stood out for hectoliter weight, presenting the best performances by the methods of Annicchiarico and the MHPRVG. For thousand-grain weight, all methods showed similar results, indicating that the 'UPFA Gaudéria' genotype presented the best results. The 'URS Guapa' genotype was superior when using the methods of Eberhart \& Russel, Annicchiarico, and the MHPRVG. The uni- and multivariate methods evaluated are suitable to estimate with high confidence the adaptability and stability of cultivars for each targeted grain production, yield, and quality.
\end{abstract}

Index terms: Avena sativa, environment, genotype, plant breeding.

\section{Métodos uni e multivariados aplicados ao estudo de adaptabilidade e estabilidade em aveia-branca}

Resumo - O objetivo deste trabalho foi comparar o uso de métodos biométricos uni e multivariados na avaliação da adaptabilidade e da estabilidade de um importante grupo de cultivares de aveia-branca (Avena sativa), cultivadas no Sul do Brasil. Utilizou-se o delineamento experimental de blocos ao acaso, em arranjo fatorial 12 ambientes $x 7$ cultivares, com três repetições. A análise de variância e os métodos de Eberhart \& Russel, de Annicchiarico e da média harmônica do desempenho relativo dos valores genéticos preditos (MHPRVG) foram avaliados. Na comparação geral dos métodos, os genótipos 'UPFA Gaudéria' e 'URS Guapa' foram os mais estáveis em relação à produtividade de grãos. Os genótipos 'UPFA Gaudéria' e 'URS-21' destacaram-se em peso do hectolitro, tendo apresentado as melhores respostas pelo método de Annicchiarico e da MHPRVG. Para a massa de mil grãos, todos os métodos apresentaram resultados semelhantes, o que indica que o genótipo 'UPFA Gaudéria' apresentou os melhores resultados. O genótipo 'URS Guapa' foi superior quando foram utilizados os métodos de Eberhart \& Russel, de Annicchiarico e da MHPRVG. Os métodos uni e multivariados avaliados são adequados para estimar com confiança a adaptabilidade e a estabilidade das cultivares para cada objetivo de produção, rendimento e qualidade de grãos.

Termos para indexação: Avena sativa, ambiente, genótipos, melhoramento genético de plantas. 


\section{Introduction}

White oat (Avena sativa L.) is one of the major winter crops grown in Southern Brazil, as well as in many other parts of the world. The cereal presents considerable importance, especially due to its high quality for a wide range of uses (Marshall et al., 2013; Jamil et al., 2016). For this reason, its adaptability and stability are sought by plant breeders, as these characteristics allow farmers to grow a given cultivar in a variety of environments and managements, without losing expressive yield potential (Hawerroth et al., 2014). This is crucial since, in most cases, the genotypes developed, i.e., selected, under a specific environmental condition can display instability in grain yield and quality when introduced in another contrasting environment or atypical growing year (Crestani et al., 2010). Therefore, the proper recommendation of the best performing cultivars for each environment and management level is fundamental for farmers. In this context, important uni- and multivariate biometric methods have been developed (Cruz et al., 2012), aiming to aid in the process of obtaining information on the adaptability and stability of the group of cultivars most grown in a given region, allowing breeders to drive efficient strategies for the development of adapted and stable, improved cultivars.

Among the most acknowledged methods for estimating adaptability and stability, the one proposed by Eberhart \& Russel (1966) is one of the most widely applied. The method is based on a simple regression analysis that prioritizes and depicts a dependent variable, through the estimation of a weighted environmental index powered by the interaction of genotype $\mathrm{x}$ environments $(\mathrm{GxE})$, genotype general mean, linear regression coefficient, regression deviation variance, and coefficient of determination (Cruz et al., 2012).

The approaches based on the analysis of variance, such as the method of Annicchiarico (1992), consist in analyzing several experiments simultaneously, in which all environments are considered to unfold the sum of squares of environmental effects and GxE interactions, generating one information for each genotype under study (Cruz et al., 2014). The genotypes are, then, compared through an index that makes it possible to reveal which environments are favorable or unfavorable to them, adopting a confidence index ranging from 75 to $95 \%$. In this way, genotypes with higher magnitudes for the recommendation value are considered more stable (Pereira et al., 2009). By this approach, higher confidence indexes indicate more truthful responses and success in the recommendation of genotype stability (Gomes et al., 2002).

Another method that allows to better depict environmental effects has been proposed by Murakami \& Cruz (2004), based on a multivariate analysis that allows indicating the best genotypes for a given condition by the principle of similarity in genotype performance. The technique aims to analyze all environments simultaneously and to subsequently stratify the environments into a smaller number of strata, called factors. According to Carvalho et al. (2014), each factor will harbor the most similar and highly correlated original environments.

Applied together, the adaptability and stability estimation methods would allow revealing with higher confidence genotype performance, taking into account the variations imposed by the environment. With this purpose, Resende (2004) presented a method based on the harmonic mean of the relative performance of predicted genetic values (MHPRVG), which provides simultaneously the interpretation of the stability, adaptability, and agronomic performance estimates of genotypes. These estimates are highly accurate and have been used in several studies with crops such as corn (Souza et al., 2015), eucalyptus (Rosado et al., 2012), and cotton (Carvalho et al., 2016). However, for white oat, this method has been little or not explored at all. It should be noted that the use of a single method to evaluate the adaptability and stability of a group of cultivars may lead to errors by researchers and producers. For the correct recommendation of cultivars, an alternative is using different methodologies to evaluate both of these parameters.

The objective of this work was to compare uniand multivariate biometric methods to evaluate the adaptability and stability of an important group of white oat cultivars grown in Southern Brazil.

\section{Materials and Methods}

The assayed genotypes were an important group of white oat cultivars - Barbarasul, Brisasul, UPFA Gaudéria, URS-21, URS Guapa, URS Tarimba, and URS Taura-, which have shown high yield potential and sample the Brazilian elite germplasm. The experiments 
were performed during six growing seasons, from 2009 to 2014, at the experimental field of the plant genomics and breeding center of Universidade Federal de Pelotas, located at Capão do Leão, in the state of Rio Grande do Sul, Brazil (31 ${ }^{\circ} 47^{\prime} 58^{\prime \prime} \mathrm{S}, 52^{\circ} 31^{\prime} 02^{\prime \prime} \mathrm{W}$, at an altitude of $13.24 \mathrm{~m}$ ). The climate is characterized as Cfa according to Köppen, and the soil is an Argissolo Vermelho-Amarelo distrófico (Hapludalf), according to the Brazilian soil classification system (Santos et al., 2013). The experimental design was a randomized complete block, in a factorial arrangement of 12 growing environments x 7 genotypes, in three replicates. Since the genotypes were evaluated in only one location, the chosen environmental factor consisted of six growing seasons with and without fungicide spraying (Table 1).

The experiments were carried out in a no-tillage system, with a base fertilization of $400 \mathrm{~kg} \mathrm{ha}^{-1} \mathrm{~N}-\mathrm{P}_{2} \mathrm{O}_{5^{-}}$ $\mathrm{K}_{2} \mathrm{O}$ (05-20-20). As topdressing, $150 \mathrm{~kg} \mathrm{ha}^{-1}$ nitrogen, in the amidic form, were applied at full tillering (stage 21), according to Zadoks developmental scale (Zadoks et al., 1974). The population density used for all genotypes was 300 plants per square meter. The experimental unit was composed by five rows, which were $5 \mathrm{~m}$ long and spaced at $0.17 \mathrm{~m}$; the useful (harvested) area consisted of three central rows, totalizing $2.55 \mathrm{~m}^{2}$. All crop managements followed the recommendations of Comissão Brasileira de Pesquisa de Aveia (Deuner et al., 2014; Merotto Junior, 2014).

Plants from the harvested area of each experimental unit were used to evaluate the following traits: grain yield, corrected to $13 \%$ moisture and adjusted to $\mathrm{kg} \mathrm{ha}^{-1}$; hectoliter weight (HW), determined through a proper scale and expressed in $\mathrm{kg} \mathrm{hL}^{-1}$; and thousandgrain weight (TGW), obtained by the mass of eight subsamples of 100 grains and expressed in grams (Brasil, 2009).

The data obtained was firstly subjected to assumptions for the analysis of variance. Normality and homogeneity of variances were verified by Shapiro-Wilk's and Hartley's tests at 5\% probability, respectively (Ramalho et al., 2012). Later, the analysis of variance at $5 \%$ probability was carried out to check the existence of significant interactions between growing environments $\mathrm{x}$ white oat genotypes. The traits that showed interaction were subjected to the adaptability and stability analysis, i.e., to the methods of Eberhart \& Russel, Annicchiarico, and MHPRVG according to Resende (2004).

The method of Eberhart \& Russel is based on the following equation:

$$
\mathrm{Y}_{\mathrm{ij}}=\beta_{\mathrm{oi}}+\beta_{\mathrm{lijj}}+\delta_{\mathrm{ij}}+\varepsilon_{\mathrm{ij}}
$$

Table 1. Evaluated environments in six growing (harvest) seasons with and without spraying of fungicides to assess the adaptability and stability of white oat (Avena sativa) cultivars grown in Southern Brazil.

\begin{tabular}{lcccc}
\hline Growing environments & Harvest season & Phytosanitary management ${ }^{(1)}$ & Accumulated rainfall $(\mathrm{mm})$ & Mean temperature $\left({ }^{\circ} \mathrm{C}\right)$ \\
\hline I & 2009 & F & 527.9 & 13.74 \\
II & 2009 & WF & 527.9 & 13.74 \\
III & 2010 & F & 524.4 & 14.08 \\
IV & 2010 & WF & 524.4 & 14.08 \\
V & 2011 & F & 452.4 & 13.58 \\
VI & 2011 & WF & 452.4 & 13.58 \\
VII & 2012 & F & 541.4 & 14.96 \\
VIII & WF & 541.4 & 14.96 \\
IX & 2012 & F & 575.4 & 12.30 \\
X & 2013 & WF & 575.4 & 12.30 \\
XI & 2013 & F & 821.2 & 15.44 \\
XII & 2014 & WF & 821.2 & 15.44 \\
\hline
\end{tabular}

${ }^{(1)}$ F, with fungicide spraying, following the recommendation of Comissão Brasileira de Pesquisa de Aveia (Deuner et al., 2014); and WF, without fungicide spraying. 
where $Y_{i j}$ is the mean of the $i^{\text {th }}$ genotype in the $\mathrm{j}^{\text {th }}$ environment; $\beta_{\mathrm{oi}}$ is the general mean of the $\mathrm{i}^{\text {th }}$ genotype; $\beta_{\text {liIJ }}$ is the coefficient of linear regression, measuring the response of the $i^{\text {th }}$ genotype to environmental variation, with $I_{j}$ as the coded environmental index; $\delta_{\mathrm{ij}}$ is the regression deviation; and $\varepsilon_{\mathrm{ij}}$ is the mean experimental error. The model proposed by Eberhart $\&$ Russel (1966) aims to estimate the adaptability of each analyzed genotype through its coefficient $\left(\beta_{1}\right)$, and the estimative of the stability or phenotypic predictability of the genotype is expressed through $\delta^{2}$ (Cruz et al., 2012).

The method of Annicchiarico is based on the confidence index of recommendation (Cruz et al., 2012), obtained by the following model: $\omega \mathrm{i}=\mu_{\mathrm{i}}-\mathrm{Z}(1-\alpha) \sigma_{\mathrm{zi}}$, where $\omega \mathrm{i}$ is the confidence index $(\%) ; \mu_{\mathrm{i}}$ is the percentage mean of the $\mathrm{i}^{\text {th }}$ genotype; $\mathrm{Z}(1-\alpha)$ is the percentile of the standard normal distribution function, in which the adopted coefficient of confidence or significance was $95 \%$, i.e., $\alpha=0.05$; and $\mathrm{s}_{\mathrm{zi}}$ is the standard deviation of the percentage of $\mathrm{Zi}$ values associated with the $\mathrm{i}^{\text {th }}$ genotype.

Both the analysis of adaptability and environmental stratification, through the principle of similarity of phenotypic performance, were used for simultaneous factor analysis (Murakami \& Cruz, 2004). The used model was: $X_{j}=1_{j 1} F_{1}+1_{j 2} F_{2}+\ldots+1_{j m} F_{m}+\varepsilon_{j}$, where $X_{j}$ is the estimated variable in each plot, with $j=1,2, \ldots . \mathrm{v} ; \mathrm{l}_{\mathrm{j} 1}$ is the factorial load for the $\mathrm{j}^{\text {th }}$ variable associated with the $\mathrm{k}^{\text {th }}$ factor, with $\mathrm{k}=1,2, \ldots . \mathrm{m} ; \mathrm{F}_{\mathrm{k}}$ is the $\mathrm{k}^{\text {th }}$ common factor; and $\varepsilon_{\mathrm{j}}$ is the specific factor. Afterwards, the MHPRVG method was applied through the statistical model: $\mathrm{y}=\mathrm{X}_{\mathrm{r}}+\mathrm{Z}_{\mathrm{g}}+\mathrm{W}_{\mathrm{i}}+\mathrm{e}$, where $\mathrm{y}$ is the data vector; $\mathrm{r}$ are the fixed effects of replicates; $g$ are the random genotypic effects; $i$ are the effects of the random GxE interaction; and $\mathrm{e}$ is the random residue (Resende, 2004).

It is important to emphasize that the used methods were chosen because they consider blocks as fixed effects and are different ways of estimating adaptability and stability parameters. The statistical analyses were performed using the Genes (Cruz, 2013) and Selegen (Resende, 2007) software.

\section{Results and Discussion}

A significant interaction was found between environment and genotypes for all evaluated traits (Table 2). Within each factor, HW and TGW differed significantly for genotype effect, and all three traits for environment. These results are an initial evidence of the contrasting cultivar performance across growing environments, depicted by the adaptability and stability analysis.

Although grain yield is one of the most important traits for white oat, genotype selection should not only be based on its mean yield across years, but also on its stability (Luche et al., 2013). The 'Brisasul' genotype, for example, showed the highest mean grain yield, but is phenotypically unstable for this trait. Similar profiles were found for 'URS-21' and 'URS Guapa'; 'URS Taura' followed the same trend regarding stability, but showed the lowest yield. Therefore, these genotypes are less predictable and stable, as proven by the magnitude of $\hat{\delta}^{2}>0$ at $\alpha \leq 0.05$. The obtained estimates are reliable since the coefficients of determination $\left(\mathrm{R}^{2}\right)$ were above $85 \%$, which is considered a high value according to the classification by Cruz et al. (2012). $\mathrm{R}^{2}$ higher than $95 \%$ were indicative that the obtained values were suitable and fitted the biometric model used (Cruz et al., 2012).

When analyzing the parameters of adaptability for grain yield (Table 3), only the 'URS Tarimba' genotype presented adaptability for favorable environments ( $\left.\hat{\beta}_{1}: 1.24\right)$; therefore, this genotype shows responsiveness to environmental improvement.

Among the genotypes analyzed for HW, the highest average $\left(\hat{\beta}_{0(\mathrm{i})}\right)$ was found for 'UPFA Gaudéria' (Table 3 ). The estimates of adaptability $\left(\hat{\beta}_{1}\right)$ did not present statistical significance for this trait; however, the 'UPFA

Table 2. Summary of the joint analysis of variance and F-test for grain yield (GY), hectoliter weight (HW), and thousand-grain weight (TGW) of seven white oat (Avena sativa) cultivars grown in 12 environments in Southern Brazil.

\begin{tabular}{lcccc}
\hline Source of variation & DF & \multicolumn{3}{c}{ Mean square } \\
\cline { 3 - 5 } & & $\begin{array}{c}\text { GY } \\
\left(\mathrm{kg} \mathrm{ha}^{-1}\right)\end{array}$ & $\begin{array}{c}\mathrm{HW} \\
\left(\mathrm{kg} \mathrm{hL}^{-1}\right)\end{array}$ & $\begin{array}{c}\mathrm{TGW} \\
(\mathrm{g})\end{array}$ \\
\hline Blocks & 2 & $481,994.1$ & 9.53 & 1.25 \\
Growing environments (E) & 11 & $18,011,487.4^{*}$ & $405.77^{*}$ & $395.23^{*}$ \\
White oat genotypes (G) & 6 & $196,274.3$ & $49.95^{*}$ & $128.44^{*}$ \\
Ex G & 66 & $313,391.5^{*}$ & $32.04^{*}$ & $39.75^{*}$ \\
Residue & 167 & 122229.30 & 6.04 & 6.86 \\
\hline CV (\%) & & 16.80 & 5.29 & 8.09 \\
\hline
\end{tabular}

*Significant at $5 \%$ probability. 
Gaudéria', 'URS-21', 'URS Guapa', 'URS Tarimba', and 'URS Taura' genotypes showed low stability and predictability. The $\mathrm{R}^{2}$ were high, ranging from 77.28 to $84.45 \%$ for most of the genotypes; the exceptions were 'URS-21', with $\mathrm{R}^{2}=51.76 \%$, and 'URS Guapa', with a very low $\mathrm{R}^{2}$ of $34.12 \%$, which undermines the reliability of the results for this genotype. Higher means were found for TGW for the UPFA Gaudéria and URS Guapa cultivars (Table 3); however, only Barbarasul was specifically adapted to unfavorable environments $\left(\hat{\beta}_{1}\right)$. The 'Barbarasul', 'Brisasul', 'UPFA Gaudéria',
'URS-21', and 'URS Guapa' genotypes showed low stability and predictability. These results can be evidenced through the high $\mathrm{R}^{2}$ obtained for the UPFA Gaudéria, URS Tarimba, and URS Taura cultivars. It is important to highlight that a genotype should not be considered undesirable by only taking into account the magnitude of the $\mathrm{R}^{2}$ obtained through these analyses, but by a joint analysis of the information revealed by the genotype mean, slope, and $\delta^{2}$ (Cruz et al., 2012).

The adaptability and stability model proposed by Eberhart \& Russel showed that none of the evaluated

Table 3. Adaptability and stability estimation by the methods of Eberhart \& Russel (1966), Annicchiarico (1992), and harmonic mean of the relative performance of predicted genetic values (MHPRVG) for grain yield (GY), hectoliter weight (HW), and thousand-grain weight (TGW) of seven white oat (Avena sativa) cultivars evaluated in 12 growing environments in Southern Brazil ${ }^{(1)}$.

\begin{tabular}{|c|c|c|c|c|c|c|c|c|}
\hline \multirow{2}{*}{ Genotype } & \multicolumn{4}{|c|}{ Eberhart \& Russel (1966) } & \multicolumn{3}{|c|}{ Annicchiarico (1992) } & \multirow[t]{2}{*}{ MHPRVG $\times$ GM } \\
\hline & $\hat{\beta}_{0(\mathrm{i})}$ & $\hat{\beta}_{1(\mathrm{i})}$ & $\hat{\delta}^{2}$ & $\mathrm{R}^{2}(\%)$ & Favorable & Unfavorable & General & \\
\hline \multicolumn{9}{|c|}{ GY } \\
\hline Barbarasul & 1994 & $0.91^{\mathrm{ns}}$ & $-2663.44^{\mathrm{ns}}$ & 95.64 & 97.34 & 100.05 & 98.70 & 2020.88 \\
\hline Brisasul & 2130 & $0.90^{\text {ns }}$ & $95664.27 * *$ & 85.79 & 98.77 & 115.83 & 107.30 & 2124.39 \\
\hline UPFA Gaudéria & 2098 & $1.16^{\mathrm{ns}}$ & $26331.54^{\mathrm{ns}}$ & 95.28 & 105.57 & 91.00 & 98.28 & 2009.39 \\
\hline URS-21 & 2096 & $0.82^{\text {ns }}$ & $38779.63^{*}$ & 89.51 & 97.68 & 121.07 & 109.38 & 2135.13 \\
\hline URS Guapa & 2124 & $0.91^{\mathrm{ns}}$ & $79768.09 * *$ & 87.33 & 101.73 & 114.46 & 108.09 & 2136.14 \\
\hline URS Tarimba & 1945 & $1.24 *$ & $-17431.81^{\mathrm{ns}}$ & 98.52 & 101.00 & 70.49 & 85.75 & 1745.19 \\
\hline URS Taura & 1967 & $1.08^{\mathrm{ns}}$ & $59575.75 * *$ & 92.12 & 97.90 & 87.10 & 92.50 & 1859.52 \\
\hline \multicolumn{9}{|c|}{ HW } \\
\hline Barbarasul & 45.78 & $1.06^{\mathrm{ns}}$ & $1.42^{\mathrm{ns}}$ & 83.75 & 98.06 & 99.06 & 98.65 & 45.75 \\
\hline Brisasul & 45.96 & $1.12^{\mathrm{ns}}$ & $1.69^{\mathrm{ns}}$ & 84.45 & 99.59 & 98.50 & 98.95 & 45.86 \\
\hline UPFA Gaudéria & 48.05 & $1.06^{\mathrm{ns}}$ & $3.18^{*}$ & 79.09 & 104.34 & 103.09 & 103.61 & 47.78 \\
\hline URS-21 & 47.48 & $0.63^{\mathrm{ns}}$ & $4.90^{*}$ & 51.76 & 100.78 & 104.15 & 102.75 & 47.35 \\
\hline URS Guapa & 44.40 & $0.70^{\mathrm{ns}}$ & $17.40^{* *}$ & 34.12 & 94.57 & 97.07 & 96.03 & 44.39 \\
\hline URS Tarimba & 46.12 & $1.22^{\mathrm{ns}}$ & $6.31 * *$ & 77.28 & 100.60 & 98.24 & 99.22 & 45.91 \\
\hline URS Taura & 46.84 & $1.20^{\mathrm{ns}}$ & $4.70^{*}$ & 79.86 & 102.07 & 99.88 & 100.79 & 46.57 \\
\hline \multicolumn{9}{|c|}{ TGW } \\
\hline Barbarasul & 29.75 & $0.59 *$ & $6.41 * *$ & 47.10 & 87.74 & 98.15 & 92.94 & 29.88 \\
\hline Brisasul & 30.99 & $1.01^{\mathrm{ns}}$ & $30.76^{* *}$ & 40.98 & 101.15 & 90.79 & 95.97 & 30.54 \\
\hline UPFA Gaudéria & 34.42 & $1.35^{\mathrm{ns}}$ & $3.41 * *$ & 87.67 & 109.00 & 103.67 & 106.33 & 34.08 \\
\hline URS-21 & 30.87 & $0.80^{\mathrm{ns}}$ & $2.00 *$ & 76.98 & 93.79 & 98.50 & 96.15 & 30.93 \\
\hline URS Guapa & 34.84 & $1.00^{\mathrm{ns}}$ & $18.92^{* *}$ & 51.06 & 107.71 & 109.07 & 108.39 & 34.43 \\
\hline URS Tarimba & 31.90 & $1.31^{\mathrm{ns}}$ & $-0.09^{\text {ns }}$ & 94.61 & 100.51 & 96.17 & 98.34 & 31.59 \\
\hline URS Taura & 32.79 & $0.94^{\mathrm{ns}}$ & $1.27^{\mathrm{ns}}$ & 84.67 & 100.11 & 103.65 & 101.88 & 32.73 \\
\hline
\end{tabular}

${ }^{(1)} \hat{\beta}_{0(\mathrm{i})}$, general mean of genotype $\mathrm{i} ; \hat{\beta}_{1(\mathrm{i})}$, coefficient of linear regression; $\hat{\delta}^{2}$, variance of regression deviations; $\mathrm{R}^{2}$, coefficient of determination; and GM, general mean. Correlation between $\hat{\beta}_{0(\mathrm{i})}$ and $\hat{\beta}_{1(\mathrm{i})}$ for $\mathrm{GY}=-0.56$, for $\mathrm{HW}=0.14$, and for TGW $=0.61 .\left(\mathrm{H}_{0}: \hat{\beta}_{1}=1\right)$ by the t-test and $\left(\mathrm{H}_{0}: \hat{\delta}^{2}=0\right)$ by the F-test. * and $* *$ Significant at 5 and $1 \%$ probability, respectively. ${ }^{\text {ns }}$ Nonsignificant. 
genotypes had superior performance for all assayed traits and parameters. However, it is worth noting that the 'UPFA Gaudéria' genotype, with high means and a wide adaptability for all traits, presented a certain level of phenotypic instability for HW and TGW.

For grain yield, the estimate of the $i$ of Annicchiarico for the general mean of environments and favorable environments showed that $57.14 \%$ of the cultivars analyzed were lower than the median index of $100 \%$ (Table 3). For unfavorable environments, this was observed for $42.85 \%$ of the cultivars, of which URS Tarimba was the most unstable. Regarding the general mean across environments, only the URS Guapa cultivar showed a $\mathrm{i}$ higher than $100 \%$, indicating its minimum adoption risk, because its grain yield was higher than the general mean in all environments.

For HW, the i showed that the UPFA Gaudéria, URS21, and URS Taura cultivars were stable and adapted (Table 3). In favorable environments, the same trends were observed for the URS Tarimba cultivar, whereas, in unfavorable ones, only UPFA Gaudéria and URS-21 showed higher performance in all tested environments, being characterized as more stable and predictable. Finally, for TGW, the UPFA Gaudéria, URS Guapa, and URS Taura cultivars presented higher values, both in favorable and unfavorable environments.

Grain yield through the MHPRVG $\times$ general mean (GM) index was an indicative that the 'URS Guapa' and 'URS-21' genotypes reached the highest predicted values, which favors them for cultivation in specific environments. However, 'URS Tarimba' and 'URS Taura' showed inferiority for this trait, meaning that great caution is necessary for their recommendation.

Regarding HW, the 'UPFA Gaudéria' and 'URS21 ' genotypes had the best performance by the MHPRVG $\times$ GM index, being suitable for cultivation when higher grain quality is the objective. 'Barbarasul' and 'URS Guapa' showed lower magnitudes for this trait, whereas 'URS-21' presented high indexes for both HW and grain yield. For TGW, the highest values were obtained for the 'URS Guapa' and 'UPFA Gaudéria' genotypes, and the lowest ones for 'Brisasul' and 'Barbarasul'.

Regarding the stability estimated by MHPRVG $\times \mathrm{GM}$, the 'UPFA Gaudéria' genotype showed to be suitable for HW and TGW, whereas 'URS Guapa' presented higher performance for grain yield and TGW. The obtained results are an indicative of the difficulty in recommending genotypes to be cultivated, targeting high grain yield and quality.

It is usually accepted that for the analysis of factors (Table 4) to have a satisfactory explanation, the higher eigenvalues should explain a minimum of $80 \%$ of total variation. In this study, four factors were necessary to explain 85.38 and $86.44 \%$ of the total variation of grain yield and HW, respectively. For TGW, only three factors were enough to explain $82.80 \%$ of total variation.

Regarding grain yield, factor I allowed grouping environments IV and V (Table 4), factor II combined environments I and II, and factor IV, environments IX and X; however, factor III did not group any of the environments. The growing environments III, VI, VII, VIII, XI, and XII were not grouped by any factor due to factorial loads below 0.70 (Cruz et al., 2014). For HW, factor I showed the potential to group environments IV, VI, and XI; factor II, environments III and V; factor III, environments I, II, and X; and factor IV, only environments V and VII. Environments VIII, IX, and XII were not grouped by any factor. Finally, for TGW, after rotation, factor I grouped environments I, III, V, and VI; factor II, only environment X; and factor III, environments II and IV. For this trait, environments VII, VIII, IX, XI, and XII did not form any groups.

The communalities for all the environments, except for environment III, were above 0.65 , which means a greater efficiency in the representation of the traits by a common part, where the intrinsic experimental errors were minimized. Magnitudes above 0.64 are considered satisfactory, because they indicate correlations above 0.80 between the standardized and the original fractions of the data (Cruz \& Carneiro, 2003). The environmental index indicated that environments III, IV, V, VI, VII, and IX were favorable; therefore, the remaining ones were considered unfavorable. However, the fact that these environments present positive or negative indexes is not a priori an indicative of correlation between environments of a same sign (Cruz \& Carneiro, 2003).

The evaluations of growing environments allow comparing the performance of genotypes under a vast range of situations. Regarding grain yield (Table 5), environments V and VI from the 2011 harvest season showed the highest estimates in the studied models. In contrast, environments XI and XII, both from the 2014 harvest season, had the lowest grain yields for 
Table 4. Summary of the factor analysis for grain yield, hectoliter weight, and thousand-grain weight of seven white oat (Avena sativa) genotypes evaluated in 12 growing environments in Southern Brazil(1).

\begin{tabular}{|c|c|c|c|c|c|c|c|c|c|}
\hline \multicolumn{3}{|c|}{ Eigenvalue estimate } & \multirow[t]{2}{*}{ E } & \multicolumn{6}{|c|}{ Factor load after rotation } \\
\hline$\hat{\lambda}$ & Proportion (\%) & Acc $(\%)$ & & Factor I & Factor II & Factor III & Factor IV & $\mathrm{C}$ & EI \\
\hline \multicolumn{10}{|c|}{ Grain yield } \\
\hline 4.14 & 34.46 & 34.46 & I & -0.19 & 0.91 & -0.06 & -0.27 & 0.95 & -370.15 \\
\hline 3.07 & 25.55 & 60.01 & II & 0.11 & 0.90 & -0.18 & 0.04 & 0.86 & -309.96 \\
\hline 1.68 & 13.99 & 74.00 & III & -0.14 & 0.12 & 0.63 & 0.10 & 0.44 & 519.74 \\
\hline 1.37 & 11.38 & 85.38 & IV & 0.84 & 0.13 & 0.19 & -0.17 & 0.79 & 180.85 \\
\hline 1.05 & 8.79 & 94.17 & V & 0.95 & -0.26 & 0.07 & 0.06 & 0.98 & 1955.42 \\
\hline 0.70 & 5.83 & 100.00 & VI & -0.36 & 0.39 & -0.83 & 0.08 & 0.98 & 1153.11 \\
\hline 0.00 & 0.00 & 100.00 & VII & -0.04 & -0.91 & -0.18 & -0.18 & 0.89 & 313.67 \\
\hline 0.00 & 0.00 & 100.00 & VIII & -0.49 & -0.64 & 0.49 & 0.30 & 0.98 & -965.73 \\
\hline 0.00 & 0.00 & 100.00 & IX & 0.04 & 0.19 & 0.14 & 0.88 & 0.83 & 317.49 \\
\hline 0.00 & 0.00 & 100.00 & $\mathrm{X}$ & -0.28 & -0.31 & -0.03 & 0.81 & 0.83 & -273.72 \\
\hline 0.00 & 0.00 & 100.00 & XI & -0.81 & -0.22 & 0.46 & 0.01 & 0.92 & -1079.54 \\
\hline 0.00 & 0.00 & 100.00 & XII & -0.65 & 0.00 & 0.46 & 0.39 & 0.79 & -1441.20 \\
\hline \multicolumn{10}{|c|}{ Hectoliter weight } \\
\hline 4.54 & 37.87 & 37.87 & I & 0.20 & 0.15 & 0.83 & 0.02 & 0.75 & 0.50 \\
\hline 2.65 & 22.11 & 59.98 & II & 0.67 & -0.01 & 0.71 & -0.15 & 0.97 & -0.42 \\
\hline 1.91 & 15.88 & 75.86 & III & 0.02 & 0.83 & -0.38 & -0.40 & 0.99 & -0.67 \\
\hline 1.27 & 10.58 & 86.44 & IV & 0.88 & 0.21 & 0.32 & 0.22 & 0.96 & -4.53 \\
\hline 1.07 & 8.90 & 95.33 & V & 0.16 & 0.92 & 0.26 & 0.72 & 0.94 & 6.10 \\
\hline 0.56 & 4.67 & 100.00 & VI & 0.73 & -0.01 & 0.58 & 0.26 & 0.94 & 4.07 \\
\hline 0.00 & 0.00 & 100.00 & VII & 0.04 & -0.07 & 0.15 & 0.95 & 0.94 & 5.00 \\
\hline 0.00 & 0.00 & 100.00 & VIII & -0.78 & -0.28 & 0.16 & 0.28 & 0.79 & -7.89 \\
\hline 0.00 & 0.00 & 100.00 & IX & -0.67 & 0.40 & -0.14 & 0.24 & 0.69 & 5.21 \\
\hline 0.00 & 0.00 & 100.00 & $\mathrm{X}$ & -0.08 & -0.07 & 0.94 & 0.05 & 0.90 & -1.26 \\
\hline 0.00 & 0.00 & 100.00 & $\mathrm{XI}$ & 0.81 & 0.00 & -0.05 & 0.41 & 0.82 & -0.41 \\
\hline 0.00 & 0.00 & 100.00 & XII & 0.08 & -0.50 & -0.23 & 0.61 & 0.68 & -5.71 \\
\hline \multicolumn{10}{|c|}{ Thousand-grain weight } \\
\hline 6.72 & 56.01 & 56.01 & I & 0.86 & -0.25 & 0.24 & & 0.86 & 0.16 \\
\hline 1.90 & 15.84 & 71.85 & II & 0.19 & -0.43 & 0.81 & . & 0.88 & -1.80 \\
\hline 1.31 & 10.95 & 82.80 & III & 0.82 & -0.13 & 0.54 & . & 0.98 & 3.63 \\
\hline 1.18 & 9.83 & 92.63 & IV & 0.18 & -0.10 & 0.88 & . & 0.82 & -0.37 \\
\hline 0.68 & 5.67 & 98.30 & V & 0.77 & -0.23 & 0.57 & . & 0.96 & 6.86 \\
\hline 0.20 & 1.70 & 100.00 & VI & 0.94 & -0.14 & 0.26 & . & 0.97 & 5.28 \\
\hline 0.00 & 0.00 & 100.00 & VII & 0.45 & 0.28 & 0.58 & . & 0.62 & -0.57 \\
\hline 0.00 & 0.00 & 100.00 & VIII & 0.58 & -0.77 & 0.24 & . & 0.99 & -6.21 \\
\hline 0.00 & 0.00 & 100.00 & IX & -0.93 & 0.33 & 0.00 & . & 0.97 & 3.69 \\
\hline 0.00 & 0.00 & 100.00 & $\mathrm{X}$ & 0.09 & 0.81 & -0.21 & . & 0.71 & 1.44 \\
\hline 0.00 & 0.00 & 100.00 & XI & 0.35 & -0.84 & -0.02 & . & 0.82 & -4.67 \\
\hline 0.00 & 0.00 & 100.00 & XII & 0.18 & -0.57 & 0.03 & . & 0.35 & -7.44 \\
\hline
\end{tabular}

(1) $\hat{\lambda}$, eigenvalues; Proportion, proportion of variation explained by eigenvalues; Acc, accumulated eigenvalues; E, environment; $\mathrm{C}$, communalities; and EI, environmental index. 
all evaluated genotypes. Climatic conditions directly influence grain yield, as the trait presents quantitative inheritance, being controlled by several genes (Araus et al., 2008). This fact explains, in part, the discrepancy in the varying magnitudes of this trait in the different harvest seasons evaluated.

For HW, environments V, VII, and IX contributed positively to the trait, whereas environments VIII and XII showed the lowest magnitudes. The environments that responded positively presented a peculiarity regarding phytosanitary management according to the recommendations of Comissão Brasileira de Pesquisa de Aveia (Deuner et al., 2014). The two environments with the lowest averages did not receive fungicide application, which is an indicative that fungicide use in the white oat crop is crucial for satisfactory grain yield and quality.

Regarding TGW, environments III and IX showed higher averages than environments VIII and XII. Grain yield was significantly affected by the modifications caused by temperature and precipitation; however, HW and TGW, which are indicative of grain quality, were highly influenced by the phytosanitary management employed during the white oat cycle. In general, environments $\mathrm{V}$ and VI stood out positively in the proposed models, and were more stable for white oat, which was related to low rainfall and temperature in this harvest season. In contrast, in environments XI and XII, the lowest averages for all evaluated traits were associated with the environments with both higher rainfall and temperatures.

The general comparison of the used methods showed that some genotypes stood out. For grain yield, 'UPFA Gaudéria' and 'URS Guapa' were more stable across 12 cultivation environments. Regarding HW, the 'UPFA Gaudéria' and 'URS-21' genotypes both presented the best performances by the methods of Annicchiarico and MHPRVG. For TGW, all methods provided similar results, revealing the best performance of the 'UPFA Gaudéria' genotype. Finally, the 'URS Guapa' genotype was superior by the methods of Eberhart \& Russel, Annicchiarico, and MHPRVG.

In general, it is not possible to pinpoint one individual genotype that stands out for all applied methods and assayed traits. This shows the difficulty of recommending a genotype as ideal for both grain yield and quality, although it is possible to recommend white oat genotypes for a specific environment.

Table 5. Estimates of environmental indexes by the methods of Eberhart \& Russel (1966), Annicchiarico (1992), and harmonic mean of the relative performance of predicted genetic values (MHPRVG) for grain yield (GY), hectoliter weight (HW), and thousand-grain weight (TGW) of seven white oat (Avena sativa) genotypes cultivated in 12 growing environments in Southern Brazil(1).

\begin{tabular}{|c|c|c|c|c|c|c|c|c|c|}
\hline \multirow{2}{*}{ Environment } & \multicolumn{3}{|c|}{ Eberhart \& Russel $^{(2)}$} & \multicolumn{3}{|c|}{ Annicchiarico $^{(2)}$} & \multicolumn{3}{|c|}{ MHPRVG $\times \mathrm{GM}^{(3)}$} \\
\hline & GY & HW & TGW & GY & HW & TGW & GY & HW & TGW \\
\hline I & $\mathrm{U}$ & $\mathrm{F}$ & $\mathrm{F}$ & $\mathrm{U}$ & $\mathrm{F}$ & $\mathrm{F}$ & $1,675.2$ & 46.91 & 32.4 \\
\hline II & $\mathrm{U}$ & $\mathrm{U}$ & $\mathrm{U}$ & $\mathrm{U}$ & $\mathrm{U}$ & $\mathrm{U}$ & $1,741.0$ & 45.95 & 30.4 \\
\hline III & $\mathrm{F}$ & $\mathrm{U}$ & $\mathrm{F}$ & $\mathrm{F}$ & $\mathrm{U}$ & $\mathrm{F}$ & $2,570.7$ & 45.7 & 35.8 \\
\hline IV & $\mathrm{F}$ & $\mathrm{U}$ & $\mathrm{U}$ & $\mathrm{F}$ & $\mathrm{U}$ & U & $2,231.8$ & 41.8 & 31.8 \\
\hline V & $\mathrm{F}$ & $\mathrm{F}$ & $\mathrm{F}$ & $\mathrm{F}$ & $\mathrm{F}$ & $\mathrm{F}$ & $4,006.4$ & 52.47 & 39.0 \\
\hline VI & $\mathrm{F}$ & $\mathrm{F}$ & $\mathrm{F}$ & $\mathrm{F}$ & $\mathrm{F}$ & $\mathrm{F}$ & $3,204.1$ & 50.4 & 37.5 \\
\hline VII & $\mathrm{F}$ & $\mathrm{F}$ & $\mathrm{U}$ & $\mathrm{F}$ & $\mathrm{F}$ & $\mathrm{U}$ & $2,364.6$ & 51.3 & 31.6 \\
\hline VIII & $\mathrm{U}$ & $\mathrm{U}$ & $\mathrm{U}$ & $\mathrm{U}$ & $\mathrm{U}$ & $\mathrm{U}$ & $1,085.2$ & 38.4 & 26.0 \\
\hline IX & $\mathrm{F}$ & $\mathrm{F}$ & F & $\mathrm{F}$ & $\mathrm{F}$ & F & $2,368.4$ & 51.5 & 35.9 \\
\hline$X$ & $\mathrm{U}$ & $\mathrm{U}$ & F & $\mathrm{U}$ & $\mathrm{U}$ & F & $1,777.2$ & 45.1 & 33.6 \\
\hline XI & $\mathrm{U}$ & $\mathrm{U}$ & $\mathrm{U}$ & $\mathrm{U}$ & $\mathrm{U}$ & $\mathrm{U}$ & 971.4 & 45.9 & 27.5 \\
\hline XII & $\mathrm{U}$ & $\mathrm{U}$ & $\mathrm{U}$ & U & $\mathrm{U}$ & $\mathrm{U}$ & 581.1 & 40.7 & 24.7 \\
\hline
\end{tabular}

${ }^{(1)}$ At $95 \%$ confidence interval. ${ }^{(2)} \mathrm{G}$, decomposition in general; F, favorable; and unfavorable environments. ${ }^{(3)} \mathrm{GM}$, general mean. 


\section{Conclusions}

1. The uni- and multivariate methods evaluated are suitable to estimate with high confidence the adaptability and stability of white oat (Avena sativa) cultivars for the targeted grain production, yield, and quality.

2. The method based on the harmonic mean of the relative performance of predicted genetic values is suitable to estimate with precision the adaptability and stability of white oat cultivars.

3. The white oat cultivars UPFA Gaudéria, URS Guapa, and URS-21 show broad adaptability and stability for hectoliter weight, thousand-grain weight, and grain yield in Southern Brazil.

\section{Acknowledgments}

To Conselho Nacional de Desenvolvimento Científico e Tecnológico (CNPq), to Coordenação de Aperfeiçoamento de Pessoal de Nível Superior (Capes), and to Fundação de Amparo à Pesquisa do Estado do Rio Grande do Sul (Fapergs), for grants and fellowships.

\section{References}

ANNICCHIARICO, P. Cultivar adaptation and recommendation from alfafa trials in Northern Italy. Journal of Genetics and Breeding, v.46, p.269-278, 1992.

ARAUS, J.L.; SLAFER, G.A.; ROYO, C.; SERRET, M.D. Breeding for yield potential and stress adaptation in cereals. Critical Reviews in Plant Science, v.27, p.377-412, 2008. DOI: https://doi.org/10.1080/07352680802467736.

BRASIL. Ministério da Agricultura, Pecuária e Abastecimento. Regras para análise de sementes. Brasília, 2009. 395p.

CARVAlHO, A.D.F. de; SILVA, G.O. da; PEREIRA, R.B.; PINHEIRO, J.B. Análise de fatores e regressão bissegmentada no estudo da adaptabilidade e estabilidade de cenoura. Revista Ceres, v.61, p.932-940, 2014. DOI: https://doi.org/10.1590/0034737X201461060007.

CARVALHO, L.P. de; FARIAS, F.J.C.; MORELLO, C. de L.; TEODORO, P.E. Selection of cotton genotypes for greater length of fibers. Crop Breeding and Applied Biotechnology, v.16, p.340347, 2016. DOI: https://doi.org/10.1590/1984-70332016v16n4n50.

CRESTANI, M.; CARVALHO, F.I.F. de; OLIVEIRA, A.C. de; SILVA, J.A.G. da; GUTKOSKI, L.C.; SARTORI, J.F.; BARBIERI, R.L.; BARETTA, D. Conteúdo de $\beta$-glucana em cultivares de aveia-branca cultivadas em diferentes ambientes. Pesquisa Agropecuária Brasileira, v.45, p.261-268, 2010. DOI: https://doi.org/10.1590/S0100-204X2010000300005.
CRUZ, C.D. GENES: a software package for analysis in experimental statistics and quantitative genetics. Acta Scientiarum. Agronomy, v.35, p.271-276, 2013. DOI: https://doi.org/10.4025/actasciagron.v35i3.21251.

CRUZ, C.D.; CARNEIRO, P.C.S. Modelos biométricos aplicados ao melhoramento genético. Viçosa: UFV, 2003. 585p.

CRUZ, C.D.; CARNEIRO, P.C.S.; REGAZZI, A.J. Modelos biométricos aplicados ao melhoramento genético. 3.ed. rev. e ampl. Viçosa: UFV, 2014. 668p.

CRUZ, C.D.; REGAZZI, A.J.; CARNEIRO, P.C.S.; Modelos biométricos aplicados ao melhoramento genético. 4.ed. Viçosa: UFV, 2012. 514p.

DEUNER, C.C.; MARTINELLI, J.A.; BOLLER, W.; SCHONS, J. Manejo de doenças. In: LÂNGARO, N.C.; CARVALHO, I.Q. de (Org.). Indicações técnicas para a cultura da aveia. Passo Fundo: Universidade de Passo Fundo, 2014. p.78-90.

EBERHART, S.A.; RUSSELL, W.A. Stability parameters for comparing varieties. Crop Science, v.6, p.36-40, 1966. DOI: https://doi.org/10.2135/cropsci1966.0011183X000600010011x.

GOMES, M. de S.; VON PINHO, R.G.; OLIVEIRA, J.S. e; RAMALHO, M.A.P.; VIANA, A.C. Adaptabilidade e estabilidade de cultivares de milho para produtividade de matéria seca e degradabilidade ruminal de silagem. Revista Brasileira de Milho e Sorgo, v.1, p.83-90, 2002. DOI: https://doi.org/10.18512/19806477/rbms.vln2p83-90.

HAWERROTH, M.C.; BARBIERI, R.L.; SILVA, J.A.G. da; CARVALHO, F.I.F. de; OLIVEIRA, A.C. de. Importância e dinâmica de caracteres na aveia produtora de grãos. Pelotas: Embrapa Clima Temperado, 2014. 56p. (Embrapa Clima Temperado. Documentos, 376).

JAMIL, M.; LATIF, N.; MANSOOR, M.; AWAN, A.A.; KHAN, A.; ELAHI, M.E.; ANWAR, F. A review on multidimensional aspects of oat (Avena sativa) crop and its nutritional, medicinal and daily life importance. World Applied Sciences Journal, v.34, p.1269-1275, 2016. DOI: https://doi.org/10.5829/idosi. wasj.2016.1269.1275.

LUCHE, H.S.; NORNBERG, R.; CRESTANI, M.; RIBEIRO, G.; WOYANN, L.G.; SILVA, J.A.G.; MAIA, L.C.; COSTA DE OLIVEIRA, A. Parâmetros de adaptabilidade e estabilidade em cultivares brasileiras e estrangeiras de aveia branca. Current Agricultural Science and Technology, v.19, p.31-40, 2013.

MARSHALL, A.; COWAN, S.; EDWARDS, S.; GRIFFITHS, I.; HOWARTH, C.; LANGDON, T.; WHITE, E. Crops that feed the world 9. Oats - a cereal crop for human and livestock feed with industrial applications. Food Security, v.5, p.13-33, 2013. DOI: https://doi.org/10.1007/s12571-012-0232-x.

MEROTTO JUNIOR, A. Manejo de plantas daninhas. In: LÂNGARO, N.C.; CARVALHO, I.Q. de (Org.). Indicações técnicas para a cultura da aveia. Passo Fundo: Universidade de Passo Fundo, 2014. p.63-68.

MURAKAMI, D.M.; CRUZ, C.D. Proposal of methodologies for environment stratification and analysis of genotype adaptability. Crop Breeding and Applied Biotechnology, v.4, p.7-11, 2004. 
PEREIRA, H.S.; MELO, L.C.; DEL PELOSO, M.J.; FARIA, L.C. de; COSTA, J.G.C. da.; DÍAZ, J.L.C.; RAVA, C.A.; WENDLAND, A. Comparação de métodos de análise de adaptabilidade e estabilidade fenotípica em feijoeiro comum. Pesquisa Agropecuária Brasileira, v.44, p.374-383, 2009. DOI: https://doi.org/10.1590/S0100-204X2009000400007.

RAMALHO, M.A.P.; FERREIRA, D.F.; OLIVEIRA, A.C. de. Experimentação em genética e melhoramento de plantas. 3.ed. Lavras: UFLA, 2012. 305p.

RESENDE, M.D.V. de. Métodos estatísticos ótimos na análise de experimentos de campo. Colombo: Embrapa Florestas, 2004. 57p. (Embrapa Florestas. Documentos, 100).

RESENDE, M.D.V. de. SELEGEN-REML/BLUP: sistema estatístico e seleção genética computadorizada via modelos lineares mistos. Colombo: Embrapa Florestas, 2007. 359p.

ROSADO, A.M.; ROSADO, T.B.; ALVES, A.A.; LAVIOLA, B.G.; BHERING, L.L. Seleção simultânea de clones de eucalipto de acordo com produtividade, estabilidade e adaptabilidade. Pesquisa Agropecuária Brasileira, v.47, p.964-971, 2012. DOI: https://doi.org/10.1590/S0100-204X2012000700013.

SANTOS, H.G. dos; JACOMINE, P.K.T.; ANJOS, L.H.C. dos; OLIVEIRA, V.A. de; LUMBRERAS, J.F.; COELHO, M.R.; ALMEIDA, J.A. de; CUNHA, T.J.F.; OLIVEIRA, J.B. de. Sistema brasileiro de classificação de solos. 3.ed. rev. e ampl. Brasília: Embrapa, 2013. 353p.

SOUZA, V.Q. de; BARETTA, D.; NARDINO, M.; CARVALHO, I.R.; FOLLMANN, D.N.; KONFLANZ, V.A.; SCHMIDT, D. Variance components and association between corn hybrids morpho-agronomic characters. Científica, v.43, p.246-253, 2015. DOI: https://doi.org/10.15361/1984-5529.2015v43n3p246-253.

ZADOKS, J.C.; CHANG, T.T.; KONZAK, C.F. A decimal code for the growth stages of cereals. Weed Research, v.14, p.415-421, 1974. DOI: https://doi.org/10.1111/j.1365-3180.1974.tb01084.x. 